\title{
Phytochemical Analysis, Nutrients and Mineral Composition of Combretum platypterum Aqueous Leaf Extract
}

\author{
"OBAZELU, PA; ARUOMAREN, A1; UGBOAJA, EE \\ Department of Medical Laboratory Science, School of Basic Medical Sciences, University of Benin, Benin City, Edo State, Nigeria. \\ *Corresponding Author Email: progress.obazelu@uniben.edu; Tel: 08056733255; Other Authors Email and Tel: \\ iroghama.aruomaren@uniben.edu; emekaekeoha@yahoo.com; Tel: 08035238969; 07067304355
}

\begin{abstract}
The Phytochemical, mineral and proximate evaluation of Combretum platypterum leaves were carried out because of its ethno medicinal uses. Aqueous leaf extract of the plant were analysed using standard methods. The phytochemical composition ( quantitative ) shows that it contains $1.344 \pm 0.05 \%$ saponin, $0.957 \pm 0.02 \%$ phenol, $0.533 \pm 0.04 \%$ tannin, $0.527 \pm 0.09 \%$ steroids, $0.356 \pm 0.02 \%$ alkaloids, $0.0667 \pm 0.01 \%$ flavonoids and $0.013 \pm 0.02 \%$ glycoside. The proximate analysis of the leaves showed that Combretum platypterum is very rich in carbohydrates $46.56 \pm 0.02 \%$, proteins $28.44 \pm 0.6$, fats $10 \pm 0.0 \%$, fibre $1.25 \pm 0.0 \%$, ash $9.5 \pm 0.2 \%$, and has a moisture content of $4.25 \pm 0.3 \%$. The minerals obtained includes; $18.4 \pm 0.02 \mathrm{mg} / \mathrm{kg}$ phosphorous, $10 \pm 0.1 \mathrm{mg} / \mathrm{kg} \mathrm{magnesium}$, $5.3 \pm 0.0 \mathrm{mg} / \mathrm{kg}$ iron, $4.8 \pm 0.2 \mathrm{mg} / \mathrm{kg}$ calcium, $0.3 \pm 0.0 \mathrm{mg} / \mathrm{kg}$ sodium, $0.07 \pm 0.0 \mathrm{mg} / \mathrm{kg}$ zinc, $0.06 \pm 0.02 \mathrm{mg} / \mathrm{kg}$ manganese and $0.11 \pm 0.0 \mathrm{mg} / \mathrm{kg}$ copper. Combretum platypterum from this study, shows that it contains nutrients, rich in minerals and phytochemicals, which if processed adequately, will provide nutritional, chemo protective and medicinal benefits to users.
\end{abstract}

\section{DOI:https://dx.doi.org/10.4314/jasem.v25i9.13}

Copyright: Copyright $\left({ }^{\circ} 2021\right.$ Obazelu et al. This is an open access article distributed under the Creative Commons Attribution License (CCL), which permits unrestricted use, distribution, and reproduction in any medium, provided the original work is properly cited.

Dates: Received: 09 May 2021; Revised: 12 August 2021; Accepted: 12 September 2021

Keywords: Combretum platypterum, mineral analysis, proximate composition, phytochemical analysis

Plants are medicinal and are of immense value to the health of individuals. Their medicinal importance lie in their bioactive components that produce physiological actions which are definite in the human body. Edeoga et al., (2005). These bioactive components (such as anthraquinones, alkaloids, steroids, phenols, flavonoids, glycosides, saponins, and tannins), vitamins and minerals can be harnessed for the treatment of different diseases. Chevalier et al., (2000). Medicinal plants have been encouraged because of their side effects which are relatively minimal, friendly environmental nature and its efficacy in some health cases and issues where orthodox medicine is ineffective. Ajayi et al., (2011) .Various parts of the plant can be used, which includes flower, root, leaves, fruit, stem and seed. Combretum platypterum is a straggling scandent shrub or a forest liana, $10 \mathrm{~m}$ long, with stem of about $10 \mathrm{~cm}$ (diameter). It belongs to the family Combretaceae. The leaves are alternate or opposite, simple, its petiole about 6-13mm long and stipules absent. It has a relative large area of distribution and seems nowhere scarce. It occurs in scrub savannah, rain forest, secondary forest, and in swampy areas. The flowers are bisexual with hypogeal seedling germination (Wickens, 1973). Local names includes; Itado dudu (Igala), mmanya nza (Igbo), okólò (igbo), ogan dudu (Dawodu), ogan ibule (Ife). It is reputed locally for its analgesic, antiarthritic, antimicrobial, antimalaria, anti-inflammatory, diarrhoea effects. Also, the leaf sap when placed in hot water can be used for hip-baths to stop bleeding from post-partum (Burkill, 1985). The stems which are hollow are used for palm wine tapping; the wood is usually hard are used for implements (small) ( Okwu and Okwu, 2004). The leaves of the plant when prepared as hot water decoctions and cold water extracts can be used as herbal remedies (Wickens, 1973). The medicinal value of Combretum platypterum has been established traditionally but there is paucity of information on its mode of activity thus the need for this scientific study.

\section{MATERIALS AND METHODS}

Plant Collection and Preparation: The leaves of Combretum platypterum were obtained from University of Benin Farm house, identified and authenticated at the Department of Plant Biology and Biotechnology, Faculty of Life Sciences, University of Benin, Benin City. About $3.65 \mathrm{~kg}$ leaves were pulverized (after drying) by commercial blender and $665 \mathrm{~g}$ of powder obtained, soaked in distilled water using $1 \mathrm{~g}$ of powder to $5 \mathrm{ml}$ of distilled water and 
allowed to stand at room temperature for 72 hours. The extract was filtered using whatman filter paper and the filtrates were concentrated to dryness at $100^{\circ} \mathrm{C}$ in a water bath, thereafter, it was put in an airtight container and refrigerated until use.

Proximate Analysis of Powdered Plant Samples: The proximate composition of the powdered plant parts were carried out according to standard methods specified by the Association of Official Analytical Chemists (AOAC, 1980), in the laboratory of the Department of Animal Science, Faculty of Agriculture, University of Benin, Benin-city.

Crude Protein Analysis by Kjeldahl method (Galyean, 2010).

$\%$ crude protein $=N_{a} \times V_{a} \times 14 / 1000 \times$

$$
V_{1} / V_{2} \times 100 / W \times 6.25
$$

Where: $\mathrm{N}_{\mathrm{a}}=$ concentration of acid $(\mathrm{HCl})$ used for titration $(0.1 \mathrm{~N}) ; \mathrm{V}_{\mathrm{a}}=$ volume of acid $(\mathrm{HCl})$ used for titration; 14 = atomic number of $\mathrm{N} ; \mathrm{V}_{1}=$ final volume of digest $(100 \mathrm{ml}) ; \mathrm{V}_{2}=$ volume of aliquot $(10 \mathrm{ml}) ; \mathrm{W}=$ weight of sample used; $6.25=$ conversion factor from Nitrogen to crude protein.

Moisture content (Galyean, 2010).

$\%$ moisture content $=($ Weight of empty beaker + sample weight $)$ $-($ Weight after drying $) \times 100$

Ash content (Galyean, 2010).

$\%$ ash $=($ Weight of Ash/Weight of sample $) \times 100$

Ether extract (Crude fat) (Galyean, 2010).

$\%$ lipids $=($ Weight of beaker and sample $)-$

(Weight after extraction) $\times 100$

Crude fibre (Galyean, 2010).

$\%$ crude fibre $=($ Oven - dry weight $)-($ Ash weight $) \times 100$

Nitrogen Free Extract (Galyean, 2010).

This is obtained by subtracting the amounts of all other five fractions from $100 \%$.

$\%$ NFE $=100-(\%$ moisture $+\%$ crude protein $+\%$ crude fibre + $\%$ ash $+\%$ crude fibre)

Determination of Minerals: Sample mineral composition was performed using the official method of AOAC. Porcelain crucible in a muffle furnace was used to dry-ash $2.0 \mathrm{~g}$ of the sample for 24 hours at 500 degree centigrade. The ash obtained was allowed to cool in a desiccator, weighed and treated with $10 \mathrm{ml}$ of $50 \% \mathrm{HCl}$. The quantification was estimated using 5 series atomic absorption spectrophotometer (AOAC, 1980).

Phytochemical Screening: Qualitative phytochemical analysis: Chemical tests were performed on the aqueous extracts for the qualitative estimation of phytochemical components using methods defined by (Harbone, 1996; Sofowora, 1993; Trease and Evans, 1989).

Test for Tannins: Into a test tube containing 20mls of water, $0.5 \mathrm{~g}$ of the dried powdered sample was added and then filtered, after which $0.1 \%$ ferricchloride (few drops) was added and detected for a brownish green or a blue-black coloration to confirm the existence of tannins (Trease and Evans, 1989).

Test for Saponins: Inside a water bath, $2 \mathrm{~g}$ of the powdered samples were boiled in $20 \mathrm{mls}$ of water, it was filtered and $10 \mathrm{mls}$ of the filtrate was mixed with $5 \mathrm{mls}$ of water and rocked for a stable persistent froth. The frothing was there after mixed with 3 drops of olive oil and observed for the emergence of an emulsion. (Trease and Evans, 1989).

Test for Flavonoids: Three methods were used to determine the existence of flavonoids: To a portion of the aqueous filtrate of each plant extract, $5 \mathrm{ml}$ of dilute ammonia solution was added, concentrated $\mathrm{H}_{2} \mathrm{SO}_{4}$ was also added immediately and observed for a yellow coloration in each extract which shows the existence of flavonoids. The yellow coloration on standing disappeared. (Trease and Evans, 1989).

To a portion of each filtrate, few drops of $1 \%$ aluminium solution were added and checked for a yellow coloration to develop, which indicates the existence of flavonoids. A portion of the individual powdered plant parts was warmed up in $10 \mathrm{ml}$ ethyl acetate over a steam bath for three minutes. The mixture was filtered and $4 \mathrm{ml}$ of the filtrate was rocked with $1 \mathrm{ml}$ of dilute ammonia solution and observed for a yellow coloration to develop, an indication of the existence of flavonoids.

Test for Steroids: To $0.5 \mathrm{~g}$ of each aqueous extract, $2 \mathrm{ml}$ of acetic anhydride was added with $2 \mathrm{ml} \mathrm{H}_{2} \mathrm{SO}_{4}$. The colour converted from violet to blue or green in some samples showing the existence of steroids (Harbone, 1996).

Test for Cardiac Glycosides (Keller-Killani test): $2 \mathrm{ml}$ glacial acetic acid (comprising a drop of ferric chloride solution under layered with $1 \mathrm{ml}$ of concentrated $\mathrm{H}_{2} \mathrm{SO}_{4}$ ) was used to treat $5 \mathrm{mls}$ of extracts. A brown 
ring on the interface suggests a deoxy sugar features of cardiac glycosides. A violet ring may occur below the brown ring, while in the acetic acid layer, a greenish ring may develop all around the thin layer (Harbone, 1996).

Test for alkaloids: A $0.5 \mathrm{~g}$ sample of the extracts was mixed with $5 \mathrm{ml}$ of $1 \%$ aqueous hydrochloric acid on a steam bath. $1 \mathrm{ml}$ of the filtrate was mixed with a few drops of Dragendorff's reagent. Turbidity with this reagent is a proof of the existence of alkaloids in the extract (Harbone, 1996).

Quantitative analysis of phytochemicals: Cyanogenic glycosides: To $2 \mathrm{~g}$ of the different plant parts, $5 \mathrm{ml}$ of alkaline picrate was added, the mixture was incubated in a wath bath for five minutes and the absorbance was read a 490nm (Onwuka, 2005).

Saponins: $5 \mathrm{ml}$ of the extract were dissolved in a solution of methanol/ water in the ratio $1: 1$. They were further dissolved in $80 \%$ methanol. $2 \mathrm{ml}$ ethanol was added, properly rocked, placed inside a water bath of $60^{\circ} \mathrm{C}$ to warm gently for ten minutes. The solutions were filtered and the absorbance read at $544 \mathrm{~nm}$. Narendra et al., (2013).

Phenols: $5 \mathrm{~g}$ of the extracts were boiled with $50 \mathrm{ml}$ of ether for five minutes and filtered, $5 \mathrm{ml}$ of the filtrate, pipette into a conical flask, and $10 \mathrm{ml}$ of distilled water was added. $2 \mathrm{ml}$ of ammonium hydroxide was added alongside $5 \mathrm{ml}$ of alcohol. They were allowed to stand for thirty minutes for full colour to improve.

The absorbance was read at $505 \mathrm{~nm}$. Edeoga et al., (2005).

Alkaloids: To $2 \mathrm{~g}$ of the plant extracts, $5 \mathrm{ml}$ of phosphate buffer solution of $\mathrm{pH} 4.7$ was added, followed by the addition of $5 \mathrm{ml}$ of bromocresol green solution and $4 \mathrm{ml}$ of chloroform. The solution rocked and there after filtered. The absorbance was read at 470nm. Narendra et al., (2013).

Steriods: To $1 \mathrm{~g}$ of plant extracts, $2 \mathrm{ml}$ of $4 \mathrm{NH}_{2} \mathrm{SO}_{4}$ and $2 \mathrm{ml}$ of $0.5 \%$ iron(III)chloride were added followed by the addition of $0.5 \mathrm{ml}$ of $0.5 \%$ potassium hexacyanoferrate(III) solution. The mixtures were warmed up in a water bath at a temperature of $70^{\circ} \mathrm{C}$ for thirty minutes and rocked occasionally. Thereafter, they were filtered and the absorbance was read at 780nm (Trease and Evans, 1996)

Flavonoids: To $2 \mathrm{~g}$ of the extracts, $0.3 \mathrm{ml}$ of $5 \% \mathrm{NaNO}_{2}$ solution was added after five minutes. On the sixth minute, $2 \mathrm{ml}$ of $1 \mathrm{M} \mathrm{NaOH}$ added and the volume made up to $2 \mathrm{ml}$ with distilled water, the solutions were well rocked and filtered. The absorbance was read at 510nm (Boham and Kocipai, 1994).

Tannins: To $5 \mathrm{~g}$ of the samples $50 \mathrm{ml}$ of distilled water was added, the mixtures were rocked with a mechanical shaker for one hour and filtered into a volumetric flask. $5 \mathrm{ml}$ of the filtrate was pipette into a test tube and rocked with $2 \mathrm{ml}$ of $0.1 \mathrm{M} \mathrm{FeCl}$ in $0.1 \mathrm{NHCl}$ and $0.008 \mathrm{M}$ potassium ferrocyanide. The absorbance was read at $120 \mathrm{~nm}$ (Van-Burden and Robison, 1981).

Statistical Analysis: Data was evaluated using Graphpad prism 7 statistical package, California USA. Data was reported as mean \pm standard deviation. Percentages of were also calculated for the different compounds present.

\section{RESULTS AND DISCUSSION}

Table 1 revealed the qualitative analysis of the phytochemicals present in Combretum platypterum aqueous leaf extract. Alkaloid, Saponin, Phenol, Flavonoid, Tannin, Glycoside and Steroid were present. Table 2 shows the quantitative phytochemical composition expressed in percentage. The percentage saponin, phenol, tannin, steroids were $1.344 \pm 0.05$, $0.957 \pm 0.0,0.533 \pm 0.04$ and $0.527 \pm 0.09$ respectively while alkaloid, glycosides and flavonoid were $0.356 \pm$ $0.02,0.013 \pm 0.02$ and $0.067 \pm 0.01$ respectively. Table 3 shows the mean \pm SEM mineral composition (expressed in $\mathrm{mg} / \mathrm{kg}$ ) of Combretum platypterum aqueous leaf extract. Calcium (Ca), Phosphorous (P), Sodium (Na), Magnesium (Mg), Iron (Fe), Zinc ( $\mathrm{Zn})$, Manganese $(\mathrm{Mn})$ and Copper $(\mathrm{Cu})$ were found to be present with Phosphorous (18.4 \pm 0.02$)$ having the highest concentration. In decreasing order, the mineral concentration of Magnesium, Iron, Calcium and Sodium were $10.00 \pm 0.1,5.30 \pm 0.0,4.80 \pm 0.2$ and $0.30 \pm 0.02$ respectively while that of Zinc, Manganese and Copper were $0.07 \pm 0.0,0.06 \pm 0.02$ and $0.11 \pm 0.0$ respectively. Table 4 shows the mean \pm SEM proximate composition of Combretum platypterum aqueous leaf extract (expressed in percentage). Crude fat, Nitrogen free extract, Moisture content, crude fibre, Ash content and crude protein are the six categories compromising proximate composition. Nitrogen free extract has the highest percentage (46.56 \pm 0.02 ) followed closely in decreasing order by Crude protein and Crude fat with $28.44 \pm 0.6$ and $10.00 \pm 0.0$ respectively while ash content, moisture content and crude fibre sums the proximate percentage with $9.50 \pm$ $0.2,4.25 \pm 0.3$ and $1.25 \pm 0.0$ respectively. platypterum leaves showed that carbohydrate has the highest percentage $(46.56 \pm 0.02)$ followed closely in decreasing order by Crude protein and Crude fat with $28.44 \pm 0.6$ and $10 \pm 0.0$ respectively while ash 
content, moisture content and crude fibre sums the proximate percentage with $9.5 \pm 0.2,4.25 \pm 0.3$ and 1.25 \pm 0.0 respectively. Conventionally, proximate analysis play a crucial role in the assessment of plants nutritional significance.

Table 1: phytochemical composition of Combretum platypterum aqueous leaf extract expressed in percentage

\begin{tabular}{lllllll}
\hline \% Alkaloid & \%Saponin & \%Phenol & \% Flavonoid & \% Tanins & \% Glycosides & \% Steriods \\
\hline Present & Present & Present & Present & Present & Present & Present \\
\hline
\end{tabular}

Table 2: phytochemical composition of Combretum platypterum aqueous leaf extract expressed in percentage

\begin{tabular}{lllllll}
\hline \% Alkaloid & \% Saponin & \%Phenol & \% Flavonoid & \% Tanins & \% Glycosides & \% Steriods \\
\hline $0.356 \pm 0.02$ & $1.344 \pm 0.05$ & $0.957 \pm 0.02$ & $0.0667 \pm 0.01$ & $0.533 \pm 0.04$ & $0.013 \pm 0.02$ & $0.527 \pm 0.09$ \\
\hline
\end{tabular}

Table 3: mineral composition (mean \pm SEM,expressed in $\mathrm{mg} / \mathrm{kg}$ ) of Combretum platypterum aqueous leaf extract.

\begin{tabular}{llllclll}
\hline Phosphorous & Calcium & Magnesium & Sodium & Iron & Copper & Zinc & Manganese \\
\hline $18.4 \pm 0.02$ & $4.8 \pm 0.1$ & $10 \pm 0.1$ & $0.3 \pm 0.02$ & $5.3 \pm 0.0$ & $0.11 \pm 0.0$ & $0.07 \pm 0.0$ & $0.06 \pm 0.02$ \\
\hline
\end{tabular}

Table 4: proximate composition (mean \pm SEM) of Combretum platypterum aqueous leaf extract expressed in percentage.

\begin{tabular}{llcccc}
\hline Nitrogen free extract & Crude fibre & Moisture content & Ash content & Crude fat & Crude protein \\
\hline $46.56 \pm 0.02$ & $1.25 \pm 0.0$ & $4.25 \pm 0.3$ & $9.5 \pm 0.2$ & $10 \pm 0.0$ & $28.44 \pm 0.6$ \\
\hline
\end{tabular}

The proximate composition of Combretum Sena et al., (1998). The proximate analysis of Combretum platypterum revealed it to be rich in carbohydrate and protein. It contains lipids, ash in appreciable quantities while the moisture and fibre component were 4.25 and 1.25 respectively. The protein content of $28.44 \%$ in the leaves shows the plant leaves can be a useful source of dietary protein supplement for animals. The protein content is higher than $27.74 \%$ reported for Vitex doniana leaves, Moringa oleifera $(20.72 \%)$ and Leptadenia haetate leaves (19.1\%) (Wickens, 1973). The fat content obtained from this study is within the range of $8.3-27.0 \%$ as reported by some previous studies for some vegetables consumed both in Niger republic and Nigeria (Lintas, 1992; Umar et al ., (2008). Several fruits and vegetables contain dietary fibres, with the leaves containing a relatively low percentage of fibre ( about $1.25 \%$ ), while leaves of some other plants contain high fibre content and can cause irritation of the intestine, as they are low in nutrient hence humans cannot break them down so easily. Faruq et al., (2002); (Osunwole, 1999). Crude fibre has also been confirmed to diminish drastically the occurrence of breast and coronary cancer. Effiong et al., (2009); Ogbuagu and Enyinnaya (2008). It contains low percentage moisture content; $4.25 \%$ when compared with Ocimum virides $(6.83 \%)$ an edible vegetable. Pandey et al., (2006). The moisture content of any food usually serves as a scope of keeping its standard. The Ash content result $(0.138 \pm 0.33 \%)$ obtained from this study is relatively high when likened with the leaves of A. gangetica $(8.16 \%)$. The estimated carbohydrate content $(46.56 \%)$ was high when compared to Sena obtusfolia leaves (20\%) (Okudu, 2007), Amarantus incurvatus leaves (23.7\%). Dean et al., (1990), leaves of Solanum americanum 31.82\%. Faruq et al., (2002) and Mormordica balsamina leaves $(39.05 \%)$ (Hassan and Umar, 2006). Carbohydrates are great source of energy supply to brain cells, blood cells and muscles. They act as mild laxative ,contribute to fat metabolism and adds to the vastness of the diet (Osunwole, 1999). The aqueous extract of leaves of Combretum platypterum had phosphorous (18.4 \pm 0.02$)$ having the highest concentration. In decreasing order, the mineral concentration of Magnesium, Iron, Calcium and Sodium were $10 \pm 0.1 ; 5.3 \pm 0.0 ; 4.8 \pm 0.2$ and $0.3 \pm$ 0.0 respectively while that of Zinc, Manganese and Copper were $0.07 \pm 0.0 ; 0.06 \pm 0.02$ and $0.11 \pm 0.0$ respectively in $\mathrm{mg} / \mathrm{kg}$. The mineral compositions of Combretum platypterum as shown in table 2 are in substantial concentrations. Minerals play major physiologic and metabolic roles in the body system (Enechi and Odonwodo, 2003). The most abundant minerals were phosphorus and magnesium. Phosphorous aid bones and teeth formation, ATP and protein synthesis. Phosphorus and vitamin B are involved in nerve signalling, muscle contractions, kidney function and normal heartbeat, while Magnesium aids in maintaining a normal heart rhythm (James, 1995) Iron aids erythropoiesis and oxygen transport during respiration (Bahl and Bahl, 2006). Amongst the micro/trace elements, iron was the most concentrated. Iron, zinc and manganese aids in strengthening the immune system by acting as antioxidants (Wickens, 1973), similarly magnesium and zinc are also known to inhibit bleeding disorders, growth impedance, cardiomyopathy, immunologic dysfunction and muscle degeneration. Chaturvedi et al., (2004). Copper via copper proteins aid iron release into the plasma from cells (Bahl and Bahl, 2006). Sodium aids in maintenance the body's water and acid-base balance within cells and in the function of muscles and nerve impulse. Calcium (Ca) which is involved in building and supporting strong bones and teeth, is also needed for haemostasis. 
Phytochemicals are metabolites (secondary) of plants that are known to reveal diverse biochemical and pharmacological effects on living organisms (Wickens,1973). The preliminary phytochemical screening showed the existence of alkaloids, saponin, tannins, phenols, steroids, flavanoids and glycosides. The quantitative phytochemical analysis indicated that leaves of Combretum platypterum contains $1.344 \pm$ $0.05 \mathrm{mg} / \mathrm{g}$ saponin, $0.957 \pm 0.02 \mathrm{mg} / \mathrm{g}$ phenol, $0.533 \pm$ $0.04 \mathrm{mg} / \mathrm{g}$ tannin, $0.527 \pm 0.09 \mathrm{mg} / \mathrm{g}$ steroids, $0.356 \pm$ $0.02 \mathrm{mg} / \mathrm{g}$ alkaloids, $0.0667 \pm 0.03 \mathrm{mg} / \mathrm{g}$ flavonoids and $0.013 \pm 0.02 \mathrm{mg} / \mathrm{g}$ glycoside content. The presence of alkaloid support its medicinal use as an analgesic for head and back ache, joint swelling and pain in arthritis. The existence alkaloids also proposes that it may have potential antimicrobial activity. Some plants that possess alkaloids are known for reducing blood pressure and have anti-malaria properties; hence the plants of Combretum platypterum may be a good source of anti-malaria for which the root is used for traditionally (Okwu and Okwu, 2004). Flavonoids are polyphenolic compounds possessing antiviral, antitumoric and antiallergic activities (Sofowora, 1993) The existence of flavonoids may be accountable for its use as anti-inflammatory agent (Boham and Kocipai, 1994). The tannin content in the leaves support the use of the plant leaves for the treatment of swellings, wounds such as mumps and as hip-baths for postpartum bleeding. Tannins have been found to be most likely anti- parasitic, anti-viral and antibacterial agents, hastening the healing of inflamed mucous membrane and wounds Paul et al., (2012), used as astringents against diarrhoea, as diuretics as anti-inflammatory, antiseptic, and haemostatic pharmaceuticals. The relative moderate tannin, phenol and saponin content support its ethno medicinal use in treating conjunctivitis (which may be due to viral and bacterial causes), cough, fever and helminthiasis. Saponins exhibit cardioprotective measure by binding cholesterol to form insoluble complexes thus preventing cholesterol reabsorption and accumulation in serum. (Coe and Anderson, 1996); (Giovannucci, 1998). Saponin potentiates the haemolytic and antimicrobial properties of plant parts. Saponin prevents cancer by preventing DNA damage. The significant level of saponin in leaves support their use in traditional medicine. Saponin aids in eliminating viruses, bacterial and fungi infections, and have been shown to compliment the potency of some vaccines (Agoha, 1981; Pearson, 1976). Therefore the leaves of Combretum platypterum may be useful in treating some infections. Paul et al., (2012), like sexually transmitted diseases (Okwu and Okwu, 2004). Glycosides are generally regarded as anti-nutritive factors in foods, reducing the bioavailability of trace minerals like Manganese, Iron, Zinc and
Copper. However in low concentrations it may help repress colon cancer and lower blood glucose (Abulude, 2007). The low glycoside concentration may not pose any serious threat on the leaves consumption.

Conclusion: The fact that the leaves of Combretum platypterum possess useful medicinal and pharmacological properties has been established but the components that bring about these effects needs to be investigated; the results obtained from this work have therefore provided an insight into not just the chemical properties of the plant but also the concentrations in which they are present. Therefore, it is recommended that the toxicity levels of the plant parts be critically examined and also the active constituents characterized and purified for the production of drugs, laboratory reagents and kits.

\section{REFERENCES}

Abulude, FO (2007). Phytochemical Screening and Mineral Contents of Leaves of Some Nigerian Woody Plants. Res. J. Phytochem. 1: 33-39.

Agoha, RC (1981). Medicinal plants of Nigeria. Pub. Health Nutr. 6: $251-256$

Ajayi, I.A; Ajibade, O; Oderinde, RA (2011). Preliminary phytochemical analysis of some plant seeds. Res. J. Chem. Sci. 1(3): 58-62.

AOAC (1980). Official Method of Analysis 13th Ed. Washington D.C. Association of Official Analytical Chemists.

Bahl, A; Bahl, B (2006). Alkaloids, Advance Organic Chemistry 6th edition. S. Cahard and company ltd New Delhi, India. Pp 1194- 1249.

Boham, AB; Kocipai, AA (1994). Flavonoids and condensed tannins from leaves of Hawaiian Vaccinium vaticulation and $V$. calycinium. Pacific Sci. 48: 458 -463.

Burkill, HM (1985). The Useful Plant of West Tropical Africa, Royal Botanical Gardens Kew. ed 2. vol 1. Pp 960.

Chaturvedi, VC; Shrivastava, R; Upreti, RK (2004). Viral infections and trace elements: A complex interaction. Curr. Sci. 87: 1536-1554.

Chevalier, A (2000). Natural Health Encyclopedia of Herbal Medicine. 2nd edition Darling Kindersley Limited, New York. Pp 236-239. 
Coe, FC; Anderson, GJ (1996). Screening of Medicinal plants for bioactive compounds". J. Food Tech. 3(9): $429-431$.

Dean, PGS; Exely, D; Godwin, TW (1990). Phytochemistry, Terpenoids of specific plants", Dermos publications, London, pp. $156-157$.

Edeoga, HO; Okwu, DE; Mbaebie, BO (2005). Phytochemical constituents of some Nigerian medicinal plants. Afri. J. Biotech. 4(7): 685-688.

Effiong, GS; Ibia, TO; Udofia, US (2009). Nutritive and Energy Values of some Wild Fruit Spices in South eastern Nigerian. Elect. J. Environ Agric. Food Chem. 8(10): 917-923.

Enechi, OC; Odonwodo, I (2003). Assessment of the Phytochemical and Nutrient composition of Pulverized Root of Cissus quadrangularis. J. Bio. Res. Biotech. 1: 63-68.

Faruq, UZ; Sani, A; Hassan, LG (2002). Nig. J. Basic Appl. Sci. 11: $157-164$.

Galyean, ML (2010). Laboratory procedures in animal nutrition research. Chapter 3. Proximate analysis. pp 13-38.

Giovannucci, E (1998). Plant Bioactive Components: Phytochemistry". Bio. Res. 33; 159-165.

Harbone, ZB (1996). Phytochemical methods: A guide to modern techniques of plant Analysis, Chapman and Hall, London, pp. 52-105.

Hassan, LG; Umar, KJ (2006). Electronic J. Food Plant Chem. 3(1): $14-17$.

James, CS (1995). Analytical chemistry of food. Chapman and Hall, New York. Pp. 20-25

Lintas, C (1992). Nutritional aspects of fruits and vegetables consumption options. Mediterraunnes. 19: $79-87$.

Narendra, D; Ramalakshmi, N; Satyanarayana, B; Sudeepthi, P; Hemachakradhar, K; Pavankumarraju, N (2013). Preliminary Phytochemical Screening, Quantitative estimation and Evaluation of antimicrobial activity of Alstoniamacrophylla Stem bark. IJSIT. 2(1): 31-39.

Ogbuagu, MN; Enyinnaya, OC (2008). Nutritive and Antinutritive Composition of the pulp of Calabash (Cresentia cujete) Fruit", Proceedings of the 31st Int. Conference of the Chemical Society of Nigeria, P.T.I Effurun. Pp 477- 480.
Okudu, HO (2007). Effects of some nutrient contents of some Nigerian green leafy vegetables. Nig. $J$. Nutr. Sci. 29(1): 232-236.

Okwu, DE; Okwu, ME (2004). Chemical composition of Plant parts. J. Sustain. Agric. Environ. 6: 140-147.

Onwuka, GI (2005). Food analysis and instrumentation: Theory and practice. Naphathali prints, Nigeria. Pp 95-96.

Osunwole, SA (1999). Traditional Medicinal Uses of Selected Plants on the University of Ibadan Campus. The Nig. Field. 64: 168-173

Pandey, M; Abidi, AB; Singh, S; Singh, RP (2006). Nutritional Evaluation of Leafy Vegetable Paratha. $J$. Human Eco. 19(2): 155-156.

Paul, K; Jourma, K; Ritva, J; Harri, H; Reunaner, MA; Timo, H; Arpo, A (2012). Flavonoid intake and risk of chronic diseases. Am. J. Clin. Nutr. 76(3): $560-$ 568

Pearson, DT (1976). Methods of Food Analysis. Chemical Analysis of Food 7th ed. Churchill Livingstone Edinburgh. Pp. 324.

Sena, LP; Vanderjagt, JJ; Rivera, C; Tsin, ATC; Muhammadu, I; Mahamadu, O; Milson, M; Pastosyn, A; Glew, RH (1998). Plants Foods and Human Nutri. 52: $17-30$.

Sofowora, A (1993). Screening plants for bioactive agents. In: Medicinal Plants of Nigeria, second edition. Spectrum Books Ltd, Sunshine House Ibadan, Nigeria. Pp 134- 156.

Trease, GE; Evans, WC (1989). Phytochemicals In: Pharmacognosy, 13th ed., W.B. Saunders Publishers, Springer, Berlin. London, Pp. 176-180.

Trease, GE; Evans, WC (1996). Phytochemicals In: Pharmacognosy, 14th ed., W.B. Saunders Publishers, Springer, Berlin. London. Pp. 191-293.

Umar, KJ; Hassan, LG; Dangoggo, SM; Maigandi, SA (2008). Nutritive Value of Black Plum (V. doniana) Leaves, Proceeding of the 31st Int. Conference of the Chemical Society of Nigeria, PTA, Effurun, Delta State, Nigeria. Pp. $73-76$.

Wickens, GE (1973). Flora of Tropical East Africa: Combretaceae. East Afr. Community. 9-11.

Van -Burden, TP; Robinson, WC (1981) Formation of complexes between protein and tannin acid. J. Agric. Food Chem. 1: 77. 